India's fiscal and monetary framework: growth in an opening economy

Ashima Goyal

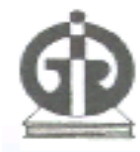

Indira Gandhi Institute of Development Research, Mumbai

December 2010

http://www.igidr.ac.in/pdf/publication/WP-2010-025.pdf 


\title{
India's fiscal and monetary framework: growth in an opening economy
}

\author{
Ashima Goyal \\ Indira Gandhi Institute of Development Research (IGIDR) \\ General Arun Kumar Vaidya Marg \\ Goregaon (E), Mumbai- 400065, INDIA \\ Email (corresponding author): $\quad$ ashima@igidr.ac.in
}

\begin{abstract}
Since a crisis is a shock impinging on a system, the response can be used to deduce aspects of the system's structure. Analysis of the crisis and recovery suggests aggregate supply in India is elastic but subject to upward shocks. This has implications for the exit and for fiscal consolidation. Both monetary and fiscal policy should identify measures that would reduce costs, while preventing too large a demand contraction. Specific policies are identified and Indian policies evaluated.
\end{abstract}

\section{Keywords:}

Crisis, fiscal and monetary policy, exit, aggregate supply elasticity

JEL Code:

E10, E52, E62

\section{Acknowledgements:}

This is a revised version of a paper written for the October 2010 ICRIER-InWEnt-DIE Conference in Mumbai and will be forthcoming in a conference volume. I thank Francis Xavier Rathinam, Ina Dettmann-Busch and conference participants for useful comments, Sanchit Arora and Shruti Tripathi for research and Reshma Aguiar for secretarial assistance. 


\title{
India's fiscal and monetary framework: growth in an opening economy
}

\author{
Ashima Goyal
}

\section{Introduction}

India's opening out coincided with a period of major global crises. The institutional changes that opened out a closed economy were the background in which fiscal and monetary policy had to respond to external shocks and domestic cycles while maintaining trend higher growth with low inflation and ensuring fiscal sustainability. India itself did not have a financial crisis although growth became volatile. There were clear benefits such as trend higher growth rate, and emergence of new growth foci. Growth was no longer government driven. But were these outcomes due to good luck or good policy? Was policy able to smooth cycles and external shocks or did it magnify them? How did it deal with policy trilemmas created by a more open capital account? What improvements does the experience of crisis and exit suggest for shortand long-term policy strategies? The paper analyzes the fiscal and monetary policy combination, the extent of stabilization, and suggests exit strategies that would benefit India while contributing to global adjustment.

Policies were procyclical in the early reform years, but the response to global crisis has demonstrated the effectiveness of countercyclical macroeconomic policies, while making clear the importance of supply-side factors for Indian inflation and of demand for output. During exit, early resurgence of inflation before recovery was well established created problems for policy. Action consistent with structure and shocks can increase growth yet reduce inflation, exchange rate regimes can contribute to these objectives, while reducing risk taking and dealing with surges of capital. The paper also analyzes other ways in which the shocks of opening out can be handled before concluding with an analysis of fiscal sustainability.

Policy recommendations include further fine-tuning stabilization policies. Short-run strategies include early, forward-looking, and therefore mild, policy responses. Instead of relying solely on reducing demand to bring down inflation, a supply-side policy 
that reduces costs is an announced conditional adjustment path to anchor inflationary expectations and prevent the second-round wage-price effects. Exchange rate appreciation is another monetary measure. Short-term fiscal measures include taxtariff rates, freer imports, and better management of food stocks. If policy created shocks work in the opposite direction to temporary supply shocks they may abort inflation, even while demand is stabilized. More flexibility of the exchange rate allows a smoother and more counter-cyclical interest rate. Its contribution to lowering inflation increases the Central Bank's ability to adapt interest rates to the domestic cycle

Longer-term strategies to reduce the distortions that create chronic inflation, include raising agricultural productivity, improving infrastructure and delivery of public services. Gradual but transparent movement towards capital account convertibility has to deepen domestic markets and risk-taking ability before allowing riskier types of foreign capital inflows. Growth will improve the fiscal position provided reforms ensure the necessary quantity and quality of expenditure for alleviating supply side bottlenecks. Incentives to improve compliance, such as selective expenditure caps and targets for individual ministries as part of better accounting and management systems are required. Caps imply countercyclical deficits as revenue falls in bad times.

Temporary widening of the current account deficit would support India's investment cycle. Short-term exchange rate appreciation would reduce inflationary pressures and the cost of imports required in the high investment phase, while contributing to demand in other countries facing a slowdown. Countries that help finance Indian infrastructure would be benefiting from Indian growth that creates demand for their own products. Reforms in the global financial architecture would reduce the necessity of self- insurance and the cost of engaging with the world, and enable faster liberalization. High transitional growth looks feasible for India but an appropriate fiscal and monetary framework can ensure it is stable and sustainable.

\section{Crisis and Exit}

This episode has faulted two myths that the media and mainstream analysts propagate about the Indian macroeconomy. Namely: inflation always indicates capacity 
constraints, and rising deficits are always a major risk. It is important to point this out because the same myths are reviving with the economy.

Table 1 shows the sharp monetary tightening raising short rates above 9 percent in the summer of 2008 precipitated a collapse in industrial output even before the September fall of Lehman. The tightening came after a period of high growth. The economy was feared to be overheating and inflation, following the international spike in fuel and food, was high. A demand shock, with a near vertical supply curve should affect inflation more than output. But the reverse happened. The wholesale price index (WPI) did not fall until November when Indian fuel prices fell, but the consumer price index remained high. The V shaped recovery also indicates a reduction in demand rather than more intractable destruction of capacity.

The sharp resurgence of WPI inflation by Q3 of 2009 was regarded as surprising since industry had barely recovered. But it should have been expected given the impact of sustained high CPI inflation on wages. Because of the latter, the manufacturing price index fell only for a few months, and had risen to its November 2008 value of 203 by April 2009. A booming economy does add pricing power, but supply side shocks explain even manufacturing inflation. So if a mild early reversal of accommodation, together with supply-side measures, anchors expected wage inflation, it reduces the need for a sharp later tightening.

The rise in government consumption compensated for the fall in private consumption and investment, and contributed to the quick recovery. An expanding fiscal deficit made this possible. Countercyclical movement in deficits is compatible with overall fiscal consolidation.

The episode also countered the belief that demand is interest inelastic in India, and output is supply determined. The impact of recently freed interest rates on elasticities, in particular on consumer durable spending, housing, etc. was not yet fully internalized. The table shows only a short lag from policy rates to industry; 2-3 quarters for a fall and one quarter for a sharp rise. Policy rates have impacted output growth since 1996. 


\begin{tabular}{|c|c|c|c|c|c|c|c|c|c|}
\hline \multicolumn{10}{|c|}{ Table 1: Crisis and Exit: Vs and Us in India } \\
\hline \multirow{2}{*}{$\begin{array}{l}\text { Indicators } \\
\text { Growth }(Y-0-Y)(\%)\end{array}$} & \multicolumn{4}{|c|}{ 2008-09: Q1-Q4 } & \multicolumn{4}{|c|}{ 2009-10: Q1-Q4 } & \multirow{2}{*}{$\begin{array}{l}\text { 2010-11: Q1 } \\
\text { Q1 }\end{array}$} \\
\hline & Q1 & Q2 & Q3 & Q4 & Q1 & Q2 & Q3 & Q4 & \\
\hline Real GDP & 7.78 & 7.46 & 6.10 & 5.76 & 6.0 & 8.6 & 6.5 & 8.6 & 8.8 \\
\hline Industry & 5.35 & 4.60 & 0.32 & 2.53 & 3.6 & 5.7 & 5.8 & 8.8 & 7.7 \\
\hline Services & 9.80 & 9.64 & 11.37 & 8.32 & 7.9 & 10.7 & 7.2 & 8.4 & 9.7 \\
\hline $\begin{array}{l}\text { Private Final Consumption } \\
\text { Expenditure }\end{array}$ & 8.44 & 7.61 & 6.40 & 5.09 & 2.9 & 6.4 & 5.3 & 2.6 & 3.8 \\
\hline $\begin{array}{l}\text { Government Final } \\
\text { Consumption Expenditure }\end{array}$ & 3.75 & 7.54 & 59.02 & 2.47 & 15.3 & 30.5 & 2.5 & 2.1 & 14.2 \\
\hline GFCF & 6.54 & 7.32 & -0.12 & 2.71 & -0.7 & 1.6 & 8.8 & 17.7 & 7.6 \\
\hline \multicolumn{10}{|l|}{ Inflation (Y-o-Y) (\%) } \\
\hline WPI & 9.57 & 12.49 & 8.57 & 3.18 & 0.54 & -0.09 & 4.98 & 10.18 & 10.98 \\
\hline CPI- Industrial Workers & 7.75 & 9.05 & 10.21 & 9.51 & 8.91 & 11.56 & 13.20 & 15.08 & 13.62 \\
\hline \multicolumn{10}{|c|}{ Money and Credit Growth (Y-O-Y) (\%) } \\
\hline Broad Money & 22.29 & 20.25 & 19.90 & 19.91 & 21.01 & 20.35 & 18.71 & 16.91 & 14.68 \\
\hline Banks Credit & 24.94 & 25.45 & 26.81 & 19.15 & 16.52 & 14.39 & 10.36 & 15.93 & 18.27 \\
\hline \multicolumn{10}{|l|}{ Interest Rates (\%) } \\
\hline Overnight (call) money & 6.83 & 9.46 & 7.80 & 4.17 & 3.22 & 3.25 & 3.20 & 3.30 & 4.16 \\
\hline 10-year g-sec & 8.26 & 8.93 & 6.63 & 8.54 & 6.67 & 7.28 & 7.59 & 7.76 & 7.62 \\
\hline \multicolumn{10}{|l|}{ Foreign Trade } \\
\hline Export Growth (\%) & 56.97 & 39.56 & -8.40 & -20.17 & -31.83 & -19.07 & 19.62 & 36.42 & 31.25 \\
\hline Import Growth (\%) & 49.00 & 61.25 & 7.43 & -25.79 & -29.7 & -31.8 & 13.9 & 61.6 & 33.8 \\
\hline \multicolumn{10}{|c|}{ Balance of Payments (US \$ billion) } \\
\hline Current Account Deficit (-) & -3.27 & -12.58 & -11.67 & -1.21 & -4.5 & -8.8 & -12.2 & -13.0 & \\
\hline Net Capital Flows & 4.85 & 7.10 & -6.11 & 1.41 & 4.0 & 18.8 & 14.7 & 16.1 & \\
\hline Reserve Outstanding & 312.10 & 286.30 & 256.00 & 252.00 & 265.1 & 281.3 & 283.5 & 279.1 & 275.7 \\
\hline
\end{tabular}

The table also shows a 3-4 quarter lag of policy rates on gross fixed capital formation (GFCF), while the revival of foreign inflows had an almost immediate impact on both industry and capital formation. The rise in exports followed the industrial recovery.

There are two types of errors made. The first assumes the final goal applies now so mature economy macroeconomic concepts can be uncritically applied to India. The second that nothing has changed so new policy instruments do not work. 
Macroeconomic policy had largely aggravated the effects of shocks rather than moderated them. But following the global demand push showed us that countercyclical macroeconomic policy was feasible and it worked. The RBI was able to manage higher government borrowings to limit crowding out of private borrowing, for example through preponing government borrowing in the period of slack private demand.

The crisis response was fast but the resurgence of inflation before recovery was firmly established led to policy dilemmas regarding exit. The response to early signs of industrial inflation was delayed, given the very large cut in interest rates that had to be reversed. The delay led to too fast a pace of increase in interest rates ${ }^{1}$ and to quantitative tightening. The latter contributed to volatility in interest rates and in industrial output. As elasticities increase and systems because more complex, blunt instruments can be phased out, or policies designed to reduce sharp changes. Policy better based on structure and shocks could more successfully smooth cycles and maintain growth.

\section{Structure and Shocks}

Mainstream macroeconomic analysis is adapted to a modern economy. Issues relating to the large informal sector, which still accounts for the major share of employment, are relegated to development economics. But once a populous emerging market crosses a critical threshold and high catch-up growth is established, higher labour mobility blurs the distinction between formal and informal sectors. A macroeconomics of the aggregate economy becomes both necessary and feasible.

Consider the Indian case. Aggregate labour supply is elastic as a large labour force shifts to more productive occupations. Higher productivity releases labour from traditional occupations, and the demographic profile ensures a steady stream of youthful entrants to the work force. Improvements in education supply, and more important, the returns to acquiring an education, ensure that new entrants have adequate skills. Higher per capita income growth with sticky consumption habits and a larger share of earners raises aggregate savings, financial deepening improves

\footnotetext{
${ }^{1}$ The operative rate went from the reverse repo at 3.25 in March 2010 to the repo at 6 by September 2010.
} 
intermediation of savings, and freer capital inflows complement domestic savings. Therefore finance is no longer a constraint.

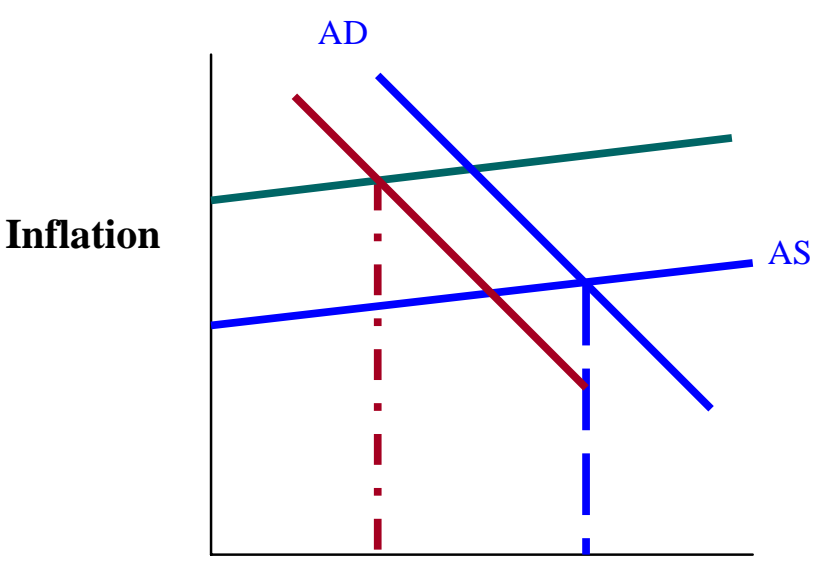

\section{Output}

Figure 1: Aggregate demand and supply

So the modern NKE apparatus (Woodford, 2003), which takes labour as the input into aggregate production, and allows specific distortions to be included, can be used. The major distortion to be modeled, for an emerging market (EM) like India, is the dualistic labour market. Capital is not a binding constraint since it is a produced means of production. Therefore the longer-run aggregate supply (LAS) is elastic (Figure 1). But such an economy is subject to inefficiencies, distortions and cost shocks. These tend to push aggregate supply upwards, but over an entire range, rather than only at full employment, since that is not reached at current output ranges and output can increase. The LAS becomes vertical only as the economy matures and full productive employment is reached.

The food price wage cycle is an important mechanism propagating price shocks and creating inflationary expectations in India, given low per capita incomes, and the large share of food in the consumption basket. Political pressures from farmers push up farm support prices, with consumption subsidies also going up. But these are inadequate due to corruption and failures of targeting, so nominal wages rise with a lag pushing up costs and generating second round inflation from a temporary supply shock. This political economy indexes wages informally to food price inflation. Political support also raises wages through minimum wages and employment 
schemes. If the rise in subsistence wages exceeds that in agricultural productivity, prices rise propagating inflation.

Monsoon failures or international oil price shocks have been dominant inflation triggers. But sustained inflation requires monetary accommodation. Prior to the nineties monetary policy routinely accommodated the populist rise in deficits. After the reforms, discontinuation of ad-hoc treasury bills, and other measures of monetary autonomy, prevented automatic financing of deficits. But reforms did not resolve supply side issues. Government spending continued to be populist. Sharp monetary tightening to reduce demand was the response to a cost shock, given political sensitivity to inflation. But a leftward shift of the demand curve along an elastic supply curve, pushed up due to supply shocks or cost creep, results in a high output loss with little effect on inflation. A mild tightening, signaling reversal of accommodation, together with supply-side polices, is sufficient to anchor inflationary expectations and shift down the supply curve. Lower interest rates encourage the supply response.

Structural VAR based tests, time series causality tests, GMM regressions of AD and AS, and calibrations in a DSGE model for such an economy Goyal (2011b) all support the elastic longer-run supply and the dominance of supply shocks ${ }^{2}$.

Calibration of exit based on this structure would include early mild tightening signaling further response as required to anchor inflationary expectations and prevent the second-round wage-price effects without a sharp demand contraction. This is an example of successful anticipation and prevention given knowledge of structure and behaviour. Instead of relying solely on reducing demand to bring down inflation, both short-term monetary and fiscal policies should shift down the supply curve. For example, exchange rate appreciation, or fiscal measures such as tax-tariff rates, and freer imports. Policy created shocks working in the opposite direction to temporary supply shocks could abort inflation. Longer-term strategies to reduce distortions that create an upward creep in the supply curve, include raising agricultural productivity,

\footnotetext{
${ }^{2}$ The analysis in this paper draws on and extends earlier work (see Goyal 2011a). More references are not given because of space constraints. They are available at www.igidr.ac.in/ ashima. Data sources are RBI, CCIL and GOI websites.
} 
changing the composition and effectiveness of public spending, improving infrastructure and delivery of public services.

Since the exchange rate regime can contribute to the above, to managing capital flows, and to coordination of the global exit, we examine it in more detail in the next section.

\section{The Exchange Rate Regime}

There has been considerable evolution in India's exchange rate regime over the reform years. The shift has been from a nominal fix to one-way movement over the nineties to two-way with low volatility implying a tightly managed exchange rate, to greater volatility and nominal movement after the global crisis (Figure 2).

Concerns to prevent appreciation in the context of a trade deficit, large but volatile inflows, and higher Indian inflation led to reserve accumulation, a tendency for nominal depreciation, and relative constancy of the real exchange rate around the real effective exchange rate (REER) established after the double devaluation in the early nineties.

But theory (Cordon, 2002, Svensson, 2000) suggests the exchange rate regime can aid other policy objectives in addition to encouraging exports and contributing to macroeconomic stabilization. It can neutralize inflationary commodity shocks, and reduce the risk taking that leads to a currency crisis. With more two-way short-term variation, more objectives can be accommodated, through more sophisticated strategies.

The average daily turnover in Indian foreign exchange (FX) markets had the fastest world growth rate from about US \$3.0 billion in 2001, to US \$34 billion in 2007, but has slowed down since (BIS, 2010). Since deepening occurred from very low levels, FX markets still have a long way to go. So periods of high volatility tend to be associated with external shocks such as the East Asian crisis (1995-98), the dot com bust and dollar decline in the new century, and the sub-prime and global economic crisis since 2007. In between there were large stretches of time with low volatility. 
Figure 2: End of Month Exchange Rate

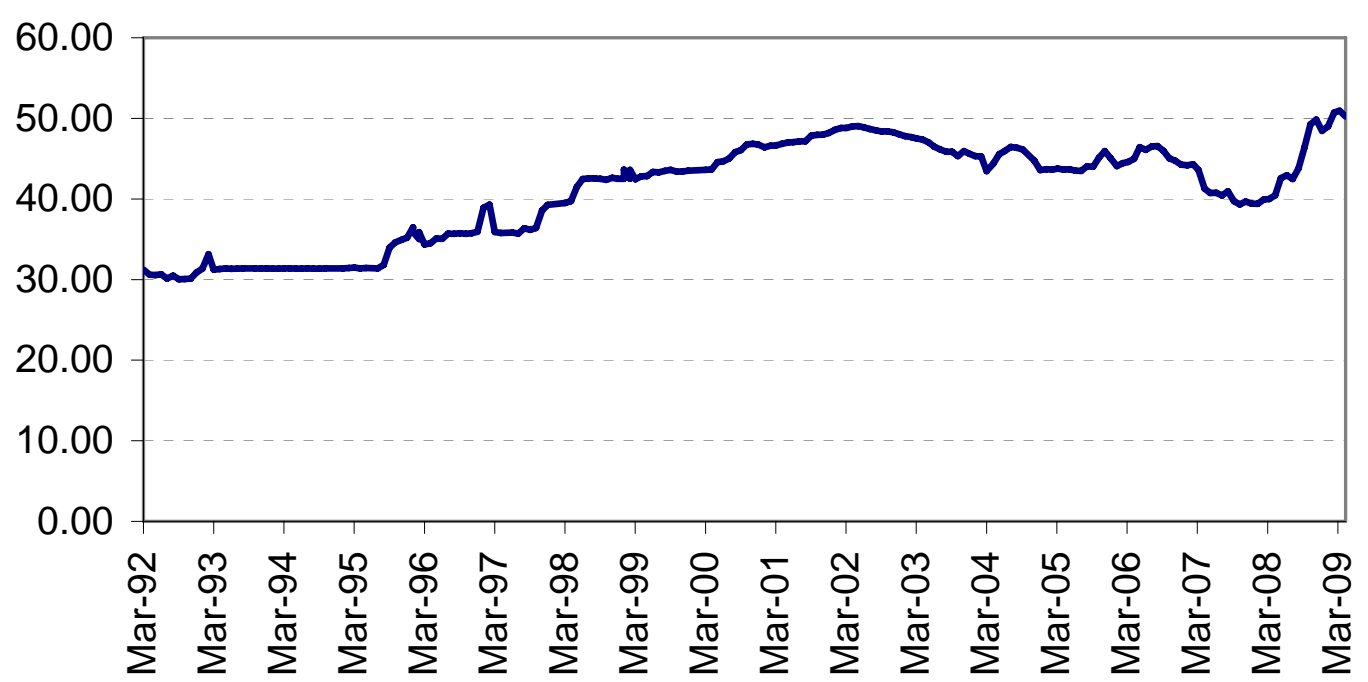

Even so, development helped the economy absorb much larger movements in capital and reserve changes in the global crisis compared to the East Asian crisis with a smaller growth contraction (Table 2). This time the interest rate defense was not used - more exchange rate flexibility was accepted. The rise in policy rates in 2008 was more in response to food and oil price shocks. It preceded the outflow-induced depreciation, and was reversed when outflows started.

After the immediate crisis, the RBI intervened less ${ }^{3}$, letting capital flows affect the exchange rate. The guiding hand deserted the markets. Swings in nominal and real exchange rates exceeded ten percent. Intervention may have been lower in order to conserve reserves at a time of great uncertainty, as the fear of floating gave way to a fear of reserve depletion, and also because reviving inflows more or less matched a widening current account deficit. But the resulting changes in the exchange rate were often opposite to what was required for macro stabilization.

\footnotetext{
${ }^{3}$ Intervention has been exactly zero since the summer of 2009, and FX market growth has slowed down in this period.
} 


\begin{tabular}{lllll}
\hline \multicolumn{5}{c}{ Table 2: Comparing volatilities during two external crises } \\
\hline Year & $\begin{array}{l}\text { Foreign } \\
\text { portfolio } \\
\text { inflows } \\
\text { (FPI)(USDb) }\end{array}$ & $\begin{array}{l}\text { Call money } \\
\text { rate (CMR) }\end{array}$ & $\begin{array}{l}\text { Change in } \\
\text { reserves (- } \\
\text { increase) } \\
\text { (USDb) }\end{array}$ & $\begin{array}{l}\text { Rate of } \\
\text { Growth } \\
\text { (GDP) }\end{array}$ \\
\hline $1994-95$ & 3.8 & 15.32 & -4.6 & 6.4 \\
$1995-96$ & 2.8 & 34.83 & 2.9 & 7.3 \\
$1997-98$ & 1.8 & 28.7 & -3.9 & 4.3 \\
$1998-99$ & -0.1 & 10.04 & -3.8 & 6.7 \\
$2007-08$ & 29.4 & 8.33 & -92.2 & 9.0 \\
$2008-09$ & -13.9 & 10.62 & 20.1 & 6.7 \\
\hline Note: The CMR is the highest average rate in any month of a year. \\
\hline \multicolumn{5}{l}{} \\
\hline
\end{tabular}

Figure 3 shows monthly changes in WPI, CPI, IIP and average inflation. In 2007 an appreciating exchange rate helped keep inflation low although oil and food prices were firming up internationally. But outflows began just as cost shocks pushed up prices. In March 2008 WPI inflation was at 7 percent. In May depreciation began and in June the WPI reached 12 percent. The supply shocks turned out to be temporary, as oil prices crashed in September, so avoiding depreciation could have moderated inflation. Instead inflation contributed to the decision to raise policy rates sharply although industrial growth was softening, and the growth collapsed.

Outflows and depreciation contributed to high CPI inflation despite the negative WPI due to the slump in world oil prices. The exchange rate fluctuated, reached its lowest level, falling below 51 in March 2009, and began sustained appreciation in April as inflows revived with Indian growth. Appreciation before export growth had recovered worked against the macroeconomic stimulus. It could not reduce the CPI inflation because of the effect of failed monsoons in raising food prices, which have a large weight in the CPI. As CPI finally fell in February 2010, outflows due to the Greek crisis depreciated the exchange rate and both WPI and CPI rose again. 
Figure 3: Monthly change inWPI, CPI, INR/USD

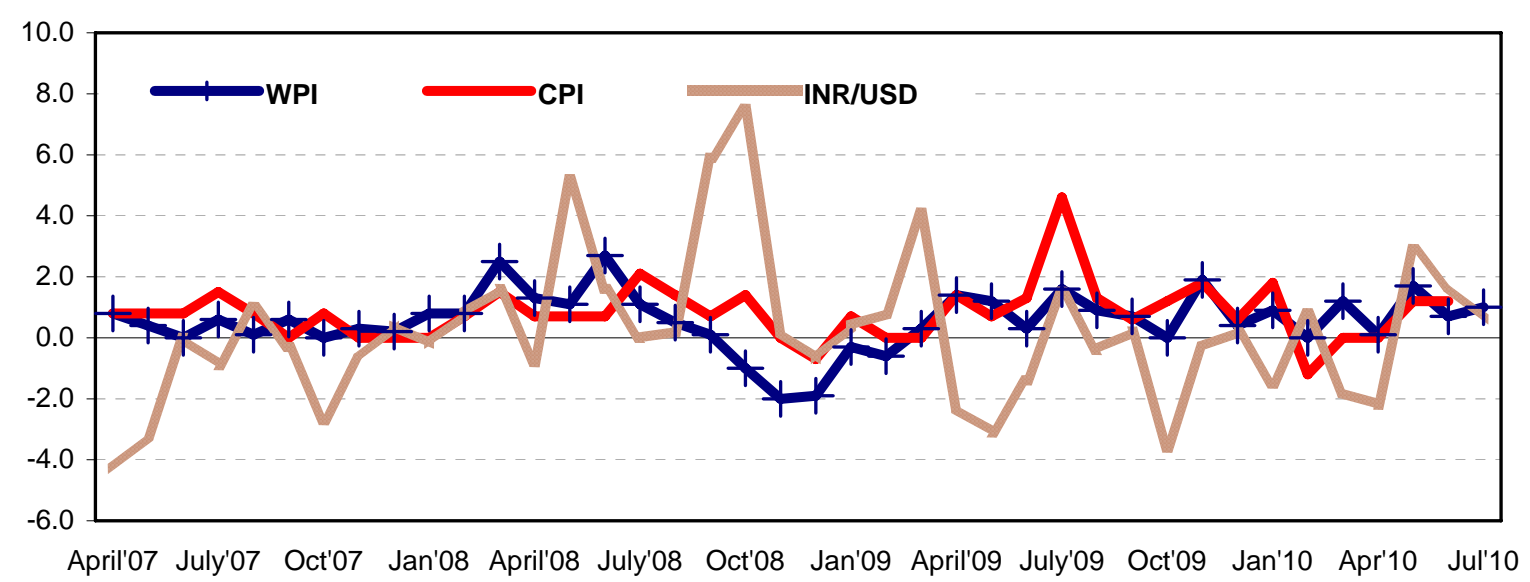

Thus the depreciations in May 2008 and May 2010 due to external events and a resulting flight to safety aggravated inflation. In thin markets large foreign capital movements can cause excessive exchange rate fluctuations, which also hurt the real sector. If a central bank does not buy/sell a currency that is not freely traded internationally, sharp spikes occur.

India cannot as yet let capital flows determine the exchange rate as a full float under capital account convertibility would imply. But the middle ground is large, and more flexibility is feasible. In the exit, since Indian inflation is higher than in the rest of the world, short-term appreciation can import low inflation at the same time increasing export demand from other countries and increasing their output. By reducing the need for a sharp rise in interest rates it will help maintain higher Indian growth, and contribute to world demand. Otherwise the inflation differential will anyway cause a real appreciation. Depreciation can follow, depending on the current account balance, after inflation subsides. Recovering world demand would help India reduce its trade deficit. In addition, active non-price polices, including diversification of destinations, could encourage exports.

The exchange rate has the shortest lag among monetary policy transmission channels. Oil dominates India's imports. Since these are quoted in dollars pass through of the exchange rate is high. As border prices begin to affect domestic food prices, the exchange rate also becomes important for the domestic political economy. Some agricultural liberalization and falling world food prices in the nineties did reduce 
political pressures on procurement prices. Inflation fell. Since appreciation following an adverse supply shock lowers intermediate goods and food prices, it pre-empts the effect of temporary supply shocks on the domestic price-wage process. Lower food price inflation would reduce the necessity for subsidies and administered prices that distort incentives and lower efficiency. Building in a rule whereby there is an automatic response to a supply shock avoids the tendency to do nothing until it becomes necessary to over-react. Actions linked to exogenous shocks also avoid moral hazard.

Such nominal changes can counter temporary shocks. But permanent shocks require productivity improvements. Without a rise in productivity, inflation would add real to the nominal appreciation, requiring nominal depreciation to correct overvaluation.

Some exchange rate volatility also forces hedging to reduce currency risk. As risk taking reduces so does the probability of currency crises. But too predictable or unidirectional movements encourage speculative positions. Despite steady reforms in Indian foreign exchange (FX) markets and some two-way rupee movement, firms lost a lot of money from bets on a trend appreciation when the global financial crisis led to large depreciation. Movement in a 10 band is sufficient to make such positions unattractive since potential losses from an incorrect position become large. Volatile movements above that level invite excessive entry of uninformed traders and below that level reduce the risk to speculative one-way bets on the exchange rate. So a plus minus five percent band is the volatility level a managed float should aim at.

Limited volatility is consistent with maintaining a trend competitive real effective exchange rate. There is evidence such volatility does not have a large effect on trade while currency crises adversely affect trade. If crises are avoided, interest rates lowered, and the exchange rate kept near competitive rates, trade is benefited.

Free capital flows and a fixed exchange rate make monetary policy ineffective since it is tied to maintaining the fixed exchange rate. The domestic interest rate must equal the international rate since any policy induced departure would lead to a flood of inflows and in order to maintain the fixed exchange rate policy must absorb the inflows, changing money supply in the process until the domestic interest rate is back 
in alignment with the international rate. For example, buying dollars to prevent appreciation when dollars flood in, if the domestic short interest rate exceeds the US interest rate, raises money supply and reduces the domestic interest rate. The incompatibility of independent monetary policy with free capital flows and a fixed exchange rate is known as the impossible trinity. Since the interest rate also has to cover expected depreciation it becomes volatile. Relative variation in nominal interest exceeded that in exchange rates initially following reforms. In the nineties, the volatility of capital flows was less than that of the current account deficit implying policy instead of smoothing shocks from openness magnified them. More flexibility of the exchange rate allows a smoother and more counter-cyclical interest rate. Its contribution to lowering inflation increases the Central Bank's ability to adapt interest rates to the domestic cycle.

Sequenced capital account restrictions and flexible exchange rates help to navigate the trinity and retain some degrees of freedom for monetary policy. That capital flows were never able to close the large differential between domestic and foreign interest rates in India suggests these degrees of freedom existed.

\section{Capital Account Restrictions}

Private Foreign Investments ${ }^{4}$ have many benefits. But especially in EMs they are subject to sudden stops or reversals. These could be due to external shocks or to infectious panics unrelated to fundamentals. India's policy strategy of “middling through" helped to reduce these risks and manage the surges. Liberalization of the capital account distinguished between types and direction of flows and was much greater for equity compared to debt flows including bank loans, and for foreign compared to domestic residents. Among debt flows long-term debt was to be liberalized before short-term. The rationale was equity, in contrast to debt, shares in and therefore reduces liabilities in a crisis. Inflows have to be allowed to go out if they are to come in, but continuing restrictions on domestic capital outflows can reduce the reserve cover required. Reversible volatile inflows were largely accumulated as reserves-a costly form of self-insurance.

\footnotetext{
${ }^{4}$ These include Foreign Direct Investment (FDI), Foreign Portfolio Investment (FPI) and other longand short-term investment flows. This section draws on Goyal 2011c
} 
Research and empirical estimation has found that only countries with strong domestic institutions, markets and government finances benefit from foreign inflows. These features determine absorptive capacity that reduces volatility and also gives countries the ability to withstand volatility. Thus the Indian strategy followed a well thought out sequence whereby full capital account liberalization was to come after deepening domestic markets, and improving government finances. Liberalizing, deepening markets and improving institutions and policy form a package. One alone is dangerous without the others. Strict sequencing is also necessary. The crisis showed that improvement in the international financial architecture and regulation are also preconditions for full capital account liberalization.

There is a perspective that regards any departure from full liberalization as a failure of reforms. But it is beginning to be recognized that it is actually a better strategy of liberalization. Lobbyists who want free foreign entry without the other harder preconditions would put the country to unnecessary risk.

Partial capital convertibility gives flexibility along the line of control, making selective tightening feasible if necessary. Additional instruments become available to tackle the policy trilemma. For example, stricter end use criteria were imposed for firms bringing funds in during periods of excessive inflows.

The strategy paid off as India avoided East European-type crisis due to excessive entry and loan pushing by banks. Despite higher volatility in narrow markets, the FPI inflows benefited firms. Loans became easier to get and more venture capital entered. Higher equity inflows were associated with higher level of domestic investment. But households did not benefit. Retail participation shrank in volatile markets. Thus foreign entry cannot resolve all problems. Other conditions also have to be in place. Eventual internationalization of Indian financial services is required as Indian companies go global. But the sequencing has to be correct. Better intermediation of the high domestic savings ratios would make markets more stable.

The Indian debt market is underdeveloped. There is zero retail participation, and caps on foreign rupee debt funds. Banks are forced to hold the large government debt through high statutory liquidity requirements (SLR). This must be brought down and 
more government debt held by households in a domestic retail market as a first step. The Greece sovereign debt crisis, and the post crisis explosion in government debts, suggests that risks associated with excessive external holding of sovereign debt will be large. India is not yet ready to face high interest volatility. Fiscal consolidation is a precondition and will be analyzed in the next section.

\section{Sustainable Debt and Fiscal Reform}

In the beginning stages of the global crisis India was regarded as high-risk because high government debt and deficit ratios limited the scope for fiscal stimulus. In the event the stimulus worked and it was one of the first countries to resume fiscal consolidation. A concept of counter cyclical deficits or cyclically adjusted fiscal balance is required.

The perception of risky deficits extrapolates unconditionally from Latin American crises, where savings rates and population densities were low, and sovereign debt was held abroad. But Indian private savings are high enough to cover for some government dissaving, thus preventing a large current account deficit and potential currency crises. Like in Japan, where the debt ratios are more than double Indian, the debt is held internally. Moreover, once high catch-up growth is established in a populous country, with a demographic profile that ensures sustained entry of youthful workers, the denominator increases so deficit and debt ratios reduce. Government expenditure that increases the supply response is sustainable. Higher growth also contributes more revenues ${ }^{5}$. Average Indian nominal interest rates exceed international and have been falling, while Indian inflation tends to be higher. A lower real interest rate means lower interest payment on past debt so lower additions to expenditures and therefore deficits. The section below demonstrates these aspects formally.

\section{Deficits and the evolution of Government debt}

The maturity value of nominal government debt $\mathrm{B}_{\mathrm{t}} \mathrm{P}_{\mathrm{t}}$, changes over time as follows:

$$
B_{t} P_{t}=\left(1+i_{t}\right) B_{t-1} P_{t-1}+\left(P_{t} G_{t}-T_{t}\right)
$$

\footnotetext{
${ }^{5}$ The ratio of Indian tax revenue to GDP, which had long stagnated in single digits, peaked at 12.6 in 2007-08 with high growth, before falling in the next crisis year to 11.8.
} 
$B_{t}$ is the maturity value of real public debt; real government purchases are $G_{t}$ and nominal net tax collections are $T_{t}$ so that real tax collections are $\tau \equiv T_{t} / P_{t}$. The real debt to output ratio is $b_{t}$. Dividing by $Y_{t}$, and making other manipulations, (1) can be written as:

$$
\frac{B_{t}}{Y_{t}}=\left(1+i_{t}\right) \frac{B_{t-1}}{Y_{t-1}} \frac{Y_{t-1}}{Y_{t}} \frac{P_{t-1}}{P_{t}}+\frac{G_{t}}{Y_{t}}-\frac{T_{t}}{P_{t} Y_{t}}
$$

Next using $1+g_{t}=Y_{t} / Y_{t-1}, 1+\pi_{t}=P_{t} / P_{t-1}$ and the approximation:

$$
\left(1+i_{t}\right) /\left(1+g_{t}\right)\left(1+\pi_{t}\right)=1+i_{t}-g_{t}-\pi_{t}
$$

Gives:

$$
b_{t}-b_{t-1}=\left(i_{t}-\pi_{t}-g_{t}\right) b_{t-1}+\frac{G_{t}}{Y_{t}}-\frac{\tau_{t}}{Y_{t}}
$$

That is, the evolution of the real debt ratio. The latter rises with the debt level, nominal interest rate, and primary deficit ratio $(p d)$ or the excess of real government expenditure over taxation as a ratio to output. Therefore high debt levels can imply exploding unsustainable debt. Falling real interest rates and rising growth rates effectively reduce government debt. Inflation and growth rates do not affect the nominal value of public debt, $\mathrm{B}_{\mathrm{t}} \mathrm{P}_{\mathrm{t}}$, which increases in any year by nominal interest payments on debt plus the $P D, P_{t} G_{t}-T_{t}$. The latter is the non-interest budget deficit, while the fiscal deficit (FD) includes interest payments and is the total governmentborrowing requirement to finance current and capital expenditure net of tax and nontax revenue. The revenue deficit (RD), or deficit on current account, is the amount the government needs to borrow to finance its own consumption. If the real interest rate equals the rate of growth, the $\mathrm{PD}$ ratio alone would add to the debt ratio. 
Figure 4 shows how the Indian debt and $p d$ has tended to fall in periods of high growth, and rise when inflation has been low and real interests high. But the fall was more convincing in the mid-nineties than it was in the mid 2000s when B actually kept rising, ending in a sharp spike in government borrowing.

Figure 4: Macroeconomic Variables and Government debt

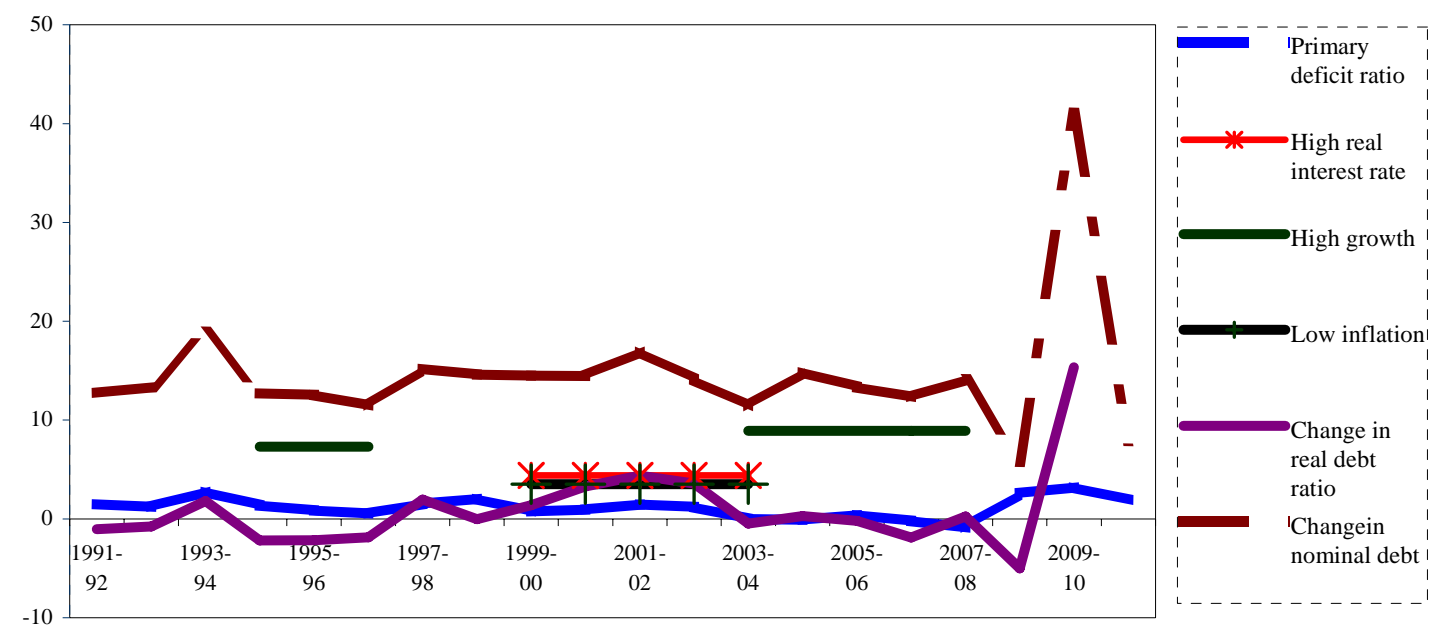

After 2003-04 nominal interest rates fell, and inflation began to rise again, driving real interest rates very low. Growth peaked at average rates of above 8 percent. The Fiscal Responsibility and Budget Management (FRBM) Act was also passed in 2003. The $p d$ fell along with the mandated fall in FD and RD. It turned into a surplus for the first time in 2004-05. Tax revenue was buoyant. But the fall in debt was not as much as these favourable conditions warranted. The goal of inclusive growth encouraged large government expenditures, as tax revenues rose with growth. Despite the FRBM, actual deficits were probably higher than reported deficits as budgetary tricks like oil bonds shifted liabilities to the future. The growth dividend was blown up in large expenditures. Therefore the $p d$ shot up in the year of the global financial crisis, and reached 3.2 percent in 2009-10. Uncovered expenditure items helped create the steep rise despite modest tax cuts, and explained the speed of the fiscal stimulus.

Goyal (2011b) allows high transitional growth in a populous low per capita income EM to reduce debt ratios as in equation (4) in a DSGE model of optimal monetaryfiscal policy adapted to EMs. A relation similar to (4) holds since there are multiple steady-states in a transitional economy. Results include: in response to a consumption shock change in government debt rises with growth, tax response, and the level of 
debt. Although lags and other structural features make for greater stability, a permanent rise in expenditure in excess of taxing capacity can lead to instability. Both the model and India's recent experience, where high growth was unable to reduce government debt, suggest improved incentives for expenditure management are required, to build robust space for countercyclical fiscal measures, and allow a cyclically adjusted fiscal balance.

In the steady state, when $b$ and other variables are constant, equation (3) reduces to b $=p d / g-r$. The budget estimate of $p d$ for 2010-11 is 1.9. Inflation reduces the real interest rate. Since there is some time for elections, the Government has put more weight on reviving growth than on reducing inflation. Inflation around seven percent reduces $r$ to 1 . Taking $g=8, p d=1.9$, the steady-state $b$ reduces to 27 percent, compared to a current debt ratio ${ }^{6}$ of around 0.8 . But inflating away debt imposes a large cost on the people and destroys goodwill for the Government. Fiscal prudence is the better way to reduce debt. Without high growth, debt can explode, so the path to a steady state would lie through a crisis.

Although reforms aimed to improve fiscal health, the norm of political populism sought inclusion through short-term transfers. The FRBM Act was not designed to protect investment, so productive expenditure was cut to continue populist spending. The former would have improved human, social, and physical capital, and therefore the supply response. The FRBM legislation brought down only reported deficits. But the global shock exposed the inadequate attention paid to incentives and escape clauses in formulating the Act. Loopholes were used to maintain the letter of the law even while violating its spirit. Targets were mechanically achieved, compressing essential expenditure on infrastructure, health and education, while maintaining populist subsidies. A new path of fiscal consolidation proposed by the $13^{\text {th }}$ Finance Commission draws heavily on and seeks to maintain India's growth dividend. There is only a gentle attempt to prevent the Centre's favorite ploy of reducing capital expenditure. Stricter constraints on the revenue deficit and more bite for the medium term fiscal plan are suggested. But more incentives are required for compliance, such as selective expenditure caps, and detailed targets for individual ministries, and levels

\footnotetext{
${ }^{6}$ Indian Central and State Government debt was 0.73 percent of GDP in March 2009.
} 
of government, as part of improved accounting, including shifts from cash to accrual based accounts. This would contribute to better governance, reducing pressures that raise costs.

There is ongoing improvement on the tax side. Apart from buoyancy due to higher growth, there were reforms in tax administration such as TIN, a proposed shift to GST and a new Direct Tax Code. If the composition of fiscal expenditure changes to improve the supply response, monetary policies can also support cyclical adjustment and growth on a more sustained basis, allowing better fiscal-monetary coordination.

\section{Conclusion}

Good luck in the shape of diversified sources sustaining Indian growth, give some leeway for policy errors Goyal (2009). Positive factors include domestic demand, agriculture, openness, technology, the demographic profile, the infrastructure cycle, high savings and having crossed a critical threshold. While foreign capital does not contribute much to aggregate resources it is useful in financial intermediation and in improvements in organization. Periods of outflow have been brief. India was one of the few economies continuing to grow even as most economies contracted in the aftermath of the financial crisis. The country may have crossed a critical threshold in its transitional catch-up phase of growth.

Good management was evident in some flexibility of exchange rates, reserve accumulation in response to volatile inflows, the strategy of graded restrictions on the capital account, steady market, institutional and regulatory development, countercyclical prudential regulations, improvements in tax administration and the enactment of the FRBM. All these helped India side-step crises, and achieve respectable growth despite financial turbulence.

So India's good performance was due to good luck and to good management. The inherent strengths of the economy helped absorb both policy mistakes and external shocks. Our policy strategy did contribute, but it was arrived at by fluke and did less than it could have, precisely because it was not properly understood or owned. It is beginning to be recognized that sequenced reforms may be a better reform strategy rather than a failure of reform. 
Improvements include more forward-looking response of policy, with exchange rates contributing to smoothing of interest rates, better composition and quality of government expenditure and governance, more focused and faster development of domestic financial intermediation; all this would better adapt macroeconomic policy to the structure of the economy.

Although improvements are possible, and one can debate timing, mix, degree and direction, policy came pretty close to finding the correct combination of reforms and of caution. On the whole regulators exhibited a healthy contrarian attitude, and democratic pulls and pressures resulted in a middling through process. This has a better chance of success in EMs needing development over several fronts to achieve robust diversified growth.

\section{References}

BIS (Bank of International Settlements). 2010. Foreign Exchange and Derivatives Market Activity in 2010. Triennial Central Bank Survey.

Corden, W.M. 2002. Too Sensational: On the Choice of Exchange Rate Regimes, Cambridge MA: MIT Press.

Goyal, A. 2009. 'Introduction: Good luck or good policy?’, Introduction to Special Issue on Indian Macroeconomic Policy and Market Development, Macroeconomics and Finance in Emerging Market Economies, 2(2), September.

Goyal, A. 2011a. 'Exchange Rate Regimes and Macroeconomic Performance in South Asia’. Routledge Handbook on South Asian Economies, (ed.) Raghbendra Jha, (2011a).

Goyal A. 2011b. 'Sustainable Debt and Deficits in Emerging Markets', International Journal of Trade and Global Markets. 4 (2): 1-23.

Goyal A. 2011c. 'Inflows and Policy: Middling Through', India Development Report 2011, D.M. Nachane (ed.), New Delhi: IGIDR and Oxford University Press.

Svensson L.E.O. 2000. 'Open-economy inflation targeting'. Journal of International Economics. 50:155-183.

Woodford, M. 2003. Interest and prices: Foundations of a Theory of Monetary Policy, NJ: Princeton University Press. 